\title{
Pessoa:
}

\section{personagens e poesia}

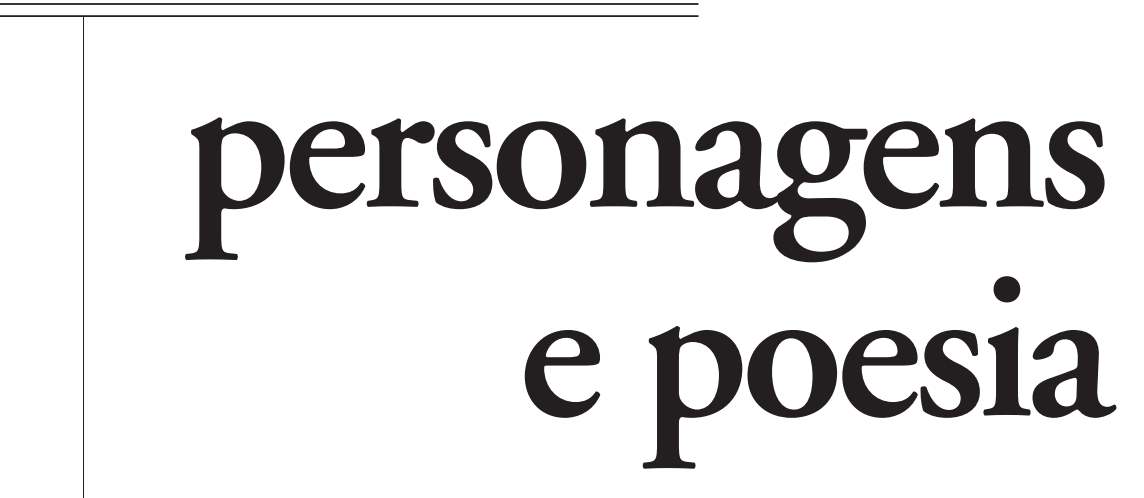

I. A PSIQUE DO POETA

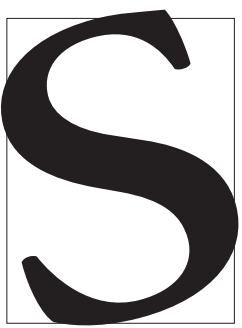

erá sem dúvida tarefa difícil e perigosa enfocar a poesia sob o ponto de vista psicológico. No entanto, o aparecimento simultâneo de uma filosofia das formas simbólicas, de uma psicologia dos símbolos e da poesia simbolista no fim do século XIX e início do XX, tornou quase irresistível a tentação de um tal enfoque.

Não pretendo, porém, de forma alguma dizer que o símbolo e com ele a poesia sejam inteiramente redutíveis ao psicológico. Pelo contrário, foi o símbolo que assumiu em nossa época uma realidade na qual se radicam tanto a poesia, como a psicologia.

Se tivéssemos que escolher cinco grandes poetas da primeira metade do século XX para exemplificar a tese acima mencionada, sem dúvida colocaríamos Fernando Pessoa entre eles. Os primeiros cinqüienta anos desse século foram extraordinariamente ricos em poesia: Rilke, 
Yeats, Pound, Eliot, Ungaretti, Maiakowski, Lorca, Antonio Machado... Seria fácil enumerar dez grandes poetas que emprestaram, paradoxalmente, à época do triunfo da tecnologia e das guerras mundiais, uma atmosfera poética comparável à dos períodos mais criativos da história. Ora, esses poetas, de um modo ou de outro, mostraram sua filiação ao simbolismo e a melhor crítica de poesia que se fez então também adotou o ponto de vista do símbolo.

Depois disso, a fonte de criatividade poética parece vir se extinguindo. Depois do esplendor dos anos 20 a 40, fulgurou ainda a chama de um St. John-Perse e o fogo lentamente se apagou. Mas este fenômeno talvez seja aparente, pois é possível que a crítica agora dominante, tanto a analítico-informática, quanto a de origem marxista, tenha sido incapaz de identificar uma nova poesia de grande valor. As correntes críticas citadas partem do princípio de que a poesia é tão-somente produção de uma pessoa: o poeta. Se a poesia, porém, emerge do símbolo (o que se subentende no pensamento simbólico) e o símbolo não é um produto pessoal, deve-se concluir que a poesia transcende a instância meramente individual. É verdade que o momento poético eclode na mente do poeta, mas mesmo assim pode não ser produzido por ele, como pessoa. Lembremos a este respeito o inconsciente coletivo, na conceituação de Jung, como fonte possível da fantasia criadora. Ele não é meu, não é teu, nem foi produzido por alguém. Em suas camadas mais profundas, nem mesmo se pode dizer que pertença à humanidade, pois suas raízes mergulham na ancestralidade telúrica do orgânico, atingindo abismos insondáveis, que podem ser assimilados ao que sempre se chamou de divino. Une a ordem urânica dos céus e as profundidades da terra com o mundo e os homens. Põe o homem dentro de uma realidade que ao mesmo tempo é dele e o ultrapassa.

A idéia romântica e pré-simbolista da poesia como verdade já a retira do contexto de produto do poeta. Para Heidegger, a obra de arte é uma coisa feita pelo homem, mas não é isto que a estabelece como obra de arte. Para ser obra de arte, essa coisafeita-pelo-homem deve revelar algo
MILTON VARGAS

é professor emérito da Escola Politécnica da Universidade de São Paulo. 
como verdade. Assim, pois, esse momento essencial da obra de arte está além do produzir humano, uma vez que para a filosofia romântica verdade é uma totalidade transcendente. A poesia como desvelamento é independente e diversa do modo ou técnica mediante os quais o produto foi produzido.

Para o simbolismo, a poesia é sempre uma manifestação do símbolo através da palavra. As palavras teriam cargas simbólicas, conotações, que se enriqueceriam ao serem habilmente justapostas na poesia. Caberia, pois, ao poeta, o manejo dos símbolos, mas estes não seriam de forma alguma produto do poeta. Seriam como que átomos de criatividade ou fontes de realidade, cuja trajetória se daria através do inconsciente que não pertence ao poeta como indivíduo.

A poesia de Fernando Pessoa, cujas raízes simbolistas são evidentes, constitui uma excelente ilustração do que foi dito acima. Manifesta-se por si mesma, como que independente da pessoa que a produziu, e de forma alguma é explicável a partir de Pessoa como indivíduo. Este desdobrava-se em pelo menos quatro personagens distintos. Como produto de uma pessoa, ou dos vários personagens, tal poesia não guarda característica alguma que a distinga univocamente. Mas dela brota algo de quem a fez: uma das maiores vozes poéticas de seu tempo.

O conceito de pessoa tem duas acepções em português: a de um centro de consciência e reflexão, como a definição de que "a alma imortal é, para o cristão, uma pessoa”. Aqui, a palavra indica um ser não só capaz de conhecer-se a si mesmo e à sua circunstância, como também de estabelecer uma relação de sujeito-objeto com as coisas que o rodeiam, além de uma relação intersubjetiva com as pessoas, sem que necessariamente com elas se confunda, ou nelas se perca. A segunda acepção é a de pessoa como personagem, istoé, de alguém que desempenha uma função, tal como na frase: “A pessoa imponente do Imperador escondia um fraco". A palavra liga-se aqui, etimologicamente, ao seu significado original de persona: máscara usada pelos ato- res do teatro antigo. O limite superior do primeiro significado ou acepção é a divindade; e o limite inferior, a aparência do farsante.

Aceitemos, pelo menos como hipótese de trabalho, que a estrutura da alma humana seja a de um ápice consciente, enraizado num substrato inconsciente. No ápice, estará a pessoa humana, enquanto o substrato carece de toda personalidade e individualidade. Confunde-se, assim, não só com o orgânico da humanidade, mas também com a região psíquica onde se encontram os modelos de todo o comportamento humano. C. G. Jung chamou às camadas mais profundas dessa região de "inconsciente coletivo", e aos modelos de comportamento, de arquétipos do inconsciente coletivo.

A palavra "pessoa" pode então significar a harmoniosa organização da alma em torno de um centro que garanta a sua individualidade. Mas pode também significar um segmento da psique coletiva que, ao invadir a alma, domina o consciente, fazendo com que o indivíduo se confunda com sua função social. É o fenômeno comum, na sociedade moderna, do indivíduo dominado por sua profissão: o senhor Diretor, o senhor Governador, etc.

O primeiro significado corresponde aproximativamente ao que Jung denominou Si-mesmo, e o segundo, à persona.

Mas das profundezas do inconsciente coletivo podem também irromper na consciência figuras numinosas (os arquétipos), a modo daqueles "estranhos deuses que vêm e vão" na floresta do que somos, vindos daquilo que não sabemos até a clareira do nosso eu conhecido (Lawrence). Sob esse ponto de vista, o poeta é o ser particularmente aberto à irrupção dos símbolos que vêm das profundezas, do "antiquiíssimo de nós”, tal como se exprime Fernando Pessoa, região que não mais nos pertence, abrangendo toda a humanidade e ancestralidade. Esta é a região do sagrado, do divino, para além do humano.

Fernando Pessoa, o poeta uno e múltiplo, mostrou-nos através de seus heterônimos como a conjunção do eu consciente do poeta com a multiplicidade da poesia 
pode dar-se. Fernando Pessoa é Alberto Caeiro, o mestre de Álvaro de Campos, mas é também este último e o seu oposto: Ricardo Reis. E é também o outro Fernando Pessoa, ele mesmo.

A Álvaro de Campos, o mais lúcido dentre eles, coube explicar o porquê dessa pluralidade:

“Quanto mais eu sinta, quanto mais eu [sinta como várias pessoas, Quanto mais personalidade eu tiver,

Quanto mais intensamente, estridentemente

[as tiver

Quanto mais simultaneamente sentir com [todas elas,

Quanto mais unificadamente diverso, [dispersamente atento

Estiver, sentir, viver, for,

Mais possuirei a existência total do

[universo,

Mais completo serei pelo espaço inteiro

[fora,

Mais análogo serei a Deus, seja ele

[quem for,

Porque, seja ele quem for, com certeza que

[é tudo

E fora d'Ele há só Ele, e Tudo para Ele [é pouco",

Essa fragmentação da personalidade não ameaçará o poeta, enquanto um centro interior as mantiver harmoniosamente consteladas, centro esse de certa forma análogo ao divino. No caso em questão, este centro consciente é Fernando Pessoa, ele mesmo, capaz de conhecer a gênese dos seus heterônimos. Diz ele: "O que Fernando Pessoa escreve pertence a duas categorias de obras a que podemos chamar de ortônimas e heterônimas. Não se poderá dizer que são anônimas ou pseudônimas; porque deveras não o são. A obra pseudônima é do autor fora de sua pessoa, de uma individualidade completamente fabricada por ele, como seriam os dizeres de qualquer personagem de qualquer drama seu".

Foi o próprio Fernando Pessoa quem contou, em carta a Casais Monteiro, que, no dia 8 de março de 1914, inclinado sobre uma cômoda alta, escrevera, de um só jato, trinta e tantos poemas de Alberto Caeiro, numa espécie de transe. Como a obra de Alberto Caeiro é constituída pelos 49 poemas do Guardador de Rebanhos e mais 35 poemas inconclusos, datados de 1911 a 1915 , conclui-se que naquela noite houve a verdadeira e quase única irrupção do personagem Caeiro na mente consciente do poeta.

Contra essa versão há o fato de o manuscrito do Guardador de Rebanhos ser datado de 1911 a 1912; no mesmo manuscrito, só alguns poemas têm a data da mencionada noite de 7 a 8 de março ao 10 de maio seguinte.

Imediatamente depois, diz ele, escreveu os seis poemas que constituem a $\mathrm{Chu}$ va Oblíqua, de Fernando Pessoa. Diz ainda na mesma carta: "Foi a reação de Fernando Pessoa contra a sua inexistência como Alberto Caeiro". Essa frase, entretanto, faz supor que o próprio Fernando Pessoa fosse um outro, pondo-se no mesmo nível de Alberto Caeiro e disputando com ele a existência. Mas há um centro de consciência, em Pessoa, que mantém o controle da individualidade, sem o que o poeta poderia perder-se na noite da loucura.

Suponho aqui que, pela madrugada daquela noite memorável, escrevesse, ao voltar a poetar como Caeiro, o final do último poema da série (o atual poema XLVI do Guardador de Rebanhos):

"Isto sinto e isto escrevo

Perfeitamente sabedor e sem que não veja Que são cinco horas do amanhecer E o sol ainda não mostrou a cabeça Por cima do muro do horizonte,

Ainda assim já se lhe vêem as pontas dos

[dedos

Agarrando o cimo do muro

Do horizonte cheio de montes baixos".

E então, como na tragédia antiga, depois de finda a luta dos deuses e mortos os heróis, a vida retoma sua normalidade. A manhã de fim de inverno alvoreceu e o poeta contemplou de sua janela o porto, a igreja, a feira, o mundo, num dia de chuva oblíqua, entremeada de raios de sol, e centrou-se de novo em si mesmo, escrevendo: 
“Atravessa esta paisagem o meu sonho dum [porto infinito

E a cor das flores é transparente de as velas [de grandes navios".

Difícil não ver, nessa chuva oblíqua de madrugada, a transição do inconsciente Caeiro para o consciente Pessoa, transformando-se lentamente um no outro. Mas, uma vez concluída a transformação, como são diversos! O mesmo tornou-se, alquimicamente, o outro.

\section{CAEIRO, O MESTRE DO SENSÍvEL}

Por que teria sido Alberto Caeiro, tal como Fernando Pessoa o declarou, o mestre dos três outros heterônimos? Sem dúvida, é ele o poeta do sensível. O que nos faz lembrar Aristóteles: "Nada há no intelecto que primeiro não estivesse nos sentidos". Assim, a primazia de Caeiro como mestre afirma primazia da sensibilidade que, nele começando, passa para a intelectualidade dos outros. Caeiro é, portanto, o corpo dos outros. Se pensa, seu pensamento é sobre as sensações, tal como o diz no poema IX do Guardador de Rebanhos:

"Sou um guardador de rebanhos O rebanho é os meus pensamentos E os meus pensamentos são todos

[sensações.

Penso com os olhos e os ouvidos

E com as mãos, e os pés

E com o nariz e a boca.

Pensar uma flor é vê-la e cheirá-la

E comer um fruto é saber-lhe o sentido.

Por isso quando num dia de calor

Me sinto triste de gozá-lo tanto,

E me deito ao comprido na erva,

E fecho os olhos quentes,

Sinto meu corpo deitado na realidade

Sei a verdade e sou feliz".

Eis o corpo! A realidade constituída pela totalidade das sensações, alcançada pelo mergulho do corpo inteiro no mar da sensibilidade. A história do Menino Jesus con- tada no poema VII é uma tentativa de trazer o paraíso cristão para o reino da sensibilidade: o Menino foge do céu, onde não há sensibilidade, e vem brincar na terra, com raios de luz e com flores e pedras, cuja grande glória é a de simplesmente existirem na plenitude de suas cores, odores e tangibilidade. Esse poema revela uma nova maneira de viver, engolfada no sensível, que é, também, uma religião. Sem dúvida alguma há, nesse poema, uma antevisão do movimento hippie, cujo Deus, necessariamente imanente, é a Criança Nova:

“A Criança Nova que habita onde vivo

Dá-me uma mão a mim

E a outra a tudo que existe

E assim vamos os três pelo caminho que [houver,

Saltando e cantando e rindo

E gozando o nosso segredo comum

Que é o saber por toda a parte

Que não há mistério no mundo

E que tudo vale a pena".

Dessa religião de um Deus imanente que parece dominar o pensamento religioso atual, nasce uma ética da sensibilidade, já prenunciada, por exemplo, por um D. H. Lawrence. Veja-se como soa lawrenciano o final do poema XXXII:

“(Louvado seja Deus que não sou bom, E tenho o egoísmo natural das flores $\mathrm{E}$ dos rios que seguem o seu caminho Preocupados sem o saber Só com fluir e ir correndo. É essa a única missão no mundo Essa - existir claramente E saber fazê-lo sem pensar nisso.) E o homem calara-se, olhando o poente. Mas que tem com o poente quem odeia e [ama?"

Compare-se esses versos com o que disse aquele suave e terrível aristocrata, filho de mineiro, que viveu na Inglaterra nessa mesma época:

"And whoeverforces himself to love anybody begets a murder in his own body". 
Entretanto, Caeiro, no seu penúltimo poema, admite que a realidade, além das sensações, tem mais uma componente. Há que fazer conjeturas sobre as sensações, e isto é o que distingue o poeta dos outros seres, pois em suas conjeturas ele chega à verdade:

“Também sei fazer conjeturas

Há em cada coisa aquilo que ela é que a [anima.

Na planta está por forae é uma ninfa pequena. No animal é um ser interior longínquo,

No homem é a alma que vive com ele e é já

[ele.

Nos deuses tem o mesmo tamanho

É o mesmo espaço que o corpo

E é a mesma cousa que o corpo.

Por isso se diz que os deuses nunca morrem.

Por isso os deuses não têm corpo e alma

Mas só corpo e são perfeitos.

O corpo é que lhes é alma

E têm a consciência na própria carne divina".

Estranha conclusão, tão lógica, a que Caeiro chega, sobre a corporalidade dos deuses. Se a realidade é inicialmente sensação sobre a qual o poeta deve conjeturar, é evidente a corporalidade dos deuses, uma vez que eles são a fonte da realidade. Só eles poderão usufruir a totalidade do real.

Sabe-se, através de Fernando Pessoa, que Alberto Caeiro só teve instrução primária. Era órfão de pai e mãe. Nasceu em 1889 e não teve profissão. Viveu quase toda a sua vida no campo, em companhia de uma tia, meio avó. Porém, com uma vida tão simples e esquemática, Caeiro é talvez o mais coerente, íntegro e conciso dos quatro heterônimos. E por isso mereceu ser o mestre de todos, recolhendo os dados da sensibilidade que depois foram elaborados pelos outros.

\section{FERNANDO PESSOA ORTÔNIMO}

Mas Fernando Pessoa não é só Caeiro; é também os três outros, sem que o ser quádruplo lhe turve a personalidade única. $\mathrm{E}$ entre os quatro, sem distinção possível, está o seu ortônimo: Fernando Pessoa.

Já se tentou mostrar como seria possível interpretar a passagem de Caeiro a Pessoa através de um dos últimos poemas do Guardador de Rebanhos, e os primeiros versos de Chuva Oblíqua, escritos na mesma famosa madrugada já citada. Foi o final da paixão noturna, quando a sensibilidade de Caeiro derramou-se, ao romper do dia, em Fernando Pessoa. Finda a alegria dos sentidos, veio a tristeza da constatação do infortúnio que rodeia o poeta - ser estranho, lançado num mundo inóspito. Caeiro não pensa, mas é coerente. Fernando Pessoa perde-se no tumulto do pensamento e foge das sensações, procurando refúgio no que não é real. Aparece então a figura do poeta, como um fingidor que finge completamente a dor que deveras sente. "E os que lêem o que escreveu/ Na dor lida sentem bem/ Não as duas que ele teve/ Mas só as que ele não tem".

Assim, segundo o que o próprio Fernando Pessoa publicou no número 17 da revista Presença, aquilo que Pessoa escreve sob outro nome não é obra pseudônima, em seu sentido mais simples, mas ortônima.

A obra de Fernando Pessoa não poderia ser simplesmente dividida em própria e heterônima e muito menos em própria e sinônima. Ela é ortônima e heterônima. Ora, ortônima quer dizer a que é certamente própria, enquanto heterônima é aquela que é certamente de outro.

Atrever-nos-emos agora a formular a seguinte teoria, deslocando a abordagem para uma análise literária e não psicológica da obra de Fernando Pessoa. O poeta, ao escrever, adotando o nome do indivíduo físico Fernando Pessoa, não se confundiria com o cidadão português que viveu sob aquele nome em Lisboa, entre 1920 e 1935.

A expressão “em sua pessoa”, designando o autor, sugere que, embora não sendo o mesmo que a pessoa física, constitui o centro consciente que dá unidade aos demais. É a pessoa de Fernando Pessoa aquele centro a que nos referimos, definindo a primeira das duas acepções do termo e equiparando-a ao Si-mesmo de Jung. Os 
heterônimos Alberto Caeiro, Ricardo Reis e Álvaro de Campos são personagens parciais, emergências do plural interior do poeta, advindas de um fundo abissal inconsciente.

Aliás, o próprio Fernando Pessoa confirma tal coisa, ao dizer que sua poesia tem o sentido teatral do drama. Isto é um fato e, como tal, poderia ser analisado objetivamente pela psicologia. Entretanto, essa análise não é nossa meta, a não ser incidentalmente, para descobrir certos condicionamentos da criatividade poética. A estrutura do psiquismo de Pessoa parece-nos realmente reveladora de algo necessário a toda criatividade poética. A pessoa (na primeira acepção do termo) do poeta é marcada indelevelmente por uma unicidade inabalável - fonte donde jorra o poema que sempre traz em si a marca única de seu criador. Mas, paradoxalmente, o poeta é também aquele que é capaz de falar através de personagens, isto é, de livrar-se de sua personalidade própria, aparecendo como outro. É capaz de “fingir" e, fingindo, comparece como personagem.

Dessa forma, a poesia de Pessoa é extremamente esclarecedora para explicar o fenômeno psicológico da criatividade poética.

Segundo C. G. Jung, a psicologia pode aparecer na obra literária de duas formas: nas chamadas obras de caráter psicológico e nas de caráter visionário. Nas primeiras, o autor discorre conscientemente sobre fatos e questões que envolvem a psicologia. Em geral, esse repertório se refere a uma série de preconceitos, crenças ou constatações subjetivas do próprio autor. No máximo, poderá haver emergências do seu inconsciente pessoal. Já na obra visionária nada se encontra de puramente subjetivo. O que aparece, através de símbolos e mitos, fatos e atos, diz respeito não à psicologia do autor, mas à psicologia coletiva. No primeiro caso, há uma fabulação consciente do autor; no segundo, irrompem forças do psiquismo, que escapam ao controle do criador. Trata-se de estratos do inconsciente coletivo - que forma o embasamento inconsciente de toda a psique humana, espécie de repositório de toda a experiência da humanidade. Como exemplos desses dois tipos de obra literária, Jung cita as duas partes do Fausto, de Goethe. Na primeira, trata-se do relato claro e consciente do drama psicológico pessoal de Fausto e de Margarida. Na segunda, já não se trata de Fausto, mas de todo o demonismo e desejo de salvação inatos na alma humana. Em lugar de Margarida aparece Helena e o Eterno Feminino.

É verdade, como diz Jung, que "a essência da obra de arte nãoé constituída pelas particularidades pessoais que pesam sobre ela (quanto mais numerosas forem as particularidades, menos se trata de arte). Pelo contrário, consiste no fato de elevar-se muito acima do pessoal". No entanto, o psiquismo do poeta é como a crisálida onde se conforma o poema e, portanto, este, de algum modo, mantém a forma mentis do poeta. Há aqui um paradoxo que o próprio Jung indica ao afirmar: "Todo ser criador representa uma dualidade ou uma síntese de dualidades paradoxais; por um lado, é homem e pessoal e, por outro, é um processo sempre humano, mas impessoal".

É inevitável, lendo essa frase, deixar de pensar na dualidade de Fernando Pessoa como ortônimo e como seus três heterônimos. Note-se bem que, segundo o próprio Pessoa, não se trata de alguém cujo nome oficial é Fernando Pessoa e que assina alguns de seus poemas construídos de modo peculiar, com pseudônimos correspondentes. Trata-se de uma estrutura psicológica constituída por um centro consciente-que se chama Fernando Pessoa-e de personagens que, como nós de energia psíquica, irrompem no consciente, dele se apoderando, e dele fazendo seu instrumento. Segundo a concepção junguiana expressa em "Psicologia e Poesia" e endereçando-a a Fernando Pessoa por minha conta: "Em última análise, o que o anima e nele quer não é ele mesmo enquanto instância pessoal, mas a obra de arte a criar".

Para conferirmos esta temática com a realidade, seria necessário recorrer a alguém que tivesse convivido com ele, e dotado de sensibilidade para captar os sinais que confirmassem ou negassem o que foi dito. Esse 
alguém felizmente existiu. Foi Casais Monteiro que nos forneceu os dados que confirmam a teoria.

Neste sentido, Casais Monteiro cita dois pontos de real importância. Primeiro, testemunha que os heterônimos não são "invenções da inteligência” de Fernando Pessoa, antes, brotando "instintiva e subconscientemente" de sua mente. De início, os personagens brotam autônomos, como no caso de Alberto Caeiro na noite de 8 de março de 1914. Só então é que o centro consciente de Pessoa os "fixa em moldes de realidade", como diz o próprio poeta em carta a Casais Monteiro: “Graduei as influências, conheci as amizades, ouvi dentro de mim as discussões e as divergências de critérios, e, em tudo isso, me parece que fui eu, criador de tudo, o menos que ali houve. Parece que tudo se passou independentemente de mim. E parece que assim se passa".

O segundo ponto importante no depoimento de Casais Monteiro é sua observação acerca da intemporalidade e da falta de evolução da poesia de Fernando Pessoa, confirmada e admitida pelo próprio poeta. Diz ele: "Tenho uma vaga idéia de ter escrito a Fernando Pessoa mais ou menos neste teor: a sua obra me parecia testemunha de uma intemporalidade quase absoluta, não havendo nela nem passado, nem futuro; mas apenas um eterno atual, que é o verdadeiro tempo em que de fato vivem os grandes imaginativos". Ao que respondeu Fernando Pessoa: “O que sou essencialmente por trás das máscaras involuntárias do poeta, do raciocinador e do que mais haja - é dramaturgo. O fenômeno da minha despersonalização instintiva... conduz naturalmente a essa definição. Sendo assim, não evoluo: VIAJO".

Ora, a intemporalidade é uma característica fundamental do inconsciente coletivo. Nele, presente, passado e futuro se presentificam nos símbolos oníricos que vêm da mais longínqua antiguidade e nos presságios que frequientemente acompanham as irrupções do inconsciente. Nada evolui, tudo é o que sempre foi na origem e tal como é agora no inconsciente. Por isso, nos sonhos, essa região aparece comumente como a dos mortos, dos túmulos e do que permanece enterrado na memória. É interessante notar como Fernando Pessoa substitui a evolução pela viagem. É que a viagem está ligada simbolicamente ao transpassar através das fronteiras do espaço e do tempo para as regiões desconhecidas e ocultas do originário: o que permanece sempre aquilo que é.

"Impressões do Crepúsculo" é uma das primeiras revelações de Fernando Pessoa, ortônimo. Numa seleção da Poesia de Fernando Pessoa, feita e prefaciada por Adolfo Casais Monteiro (Lisboa, Editorial Confluência, 1945), tal poema consta de duas partes. Na primeira, comparece a origem: "O sino da minha aldeia,/ Dolente na tarde calma,/ Cada tua badalada/ Soa dentro da minha alma". Mas é na segunda que o poeta universal diz quem é, ou, pelo, menos, quem foi de início:

“Pauis de roçarem ânsias pela minh’alma [em ouro..

Dobre longínquo de Outros Sinos...

[Empalidece o louro

Trigo na cinza do poente... Corre um frio [carnal por minh'alma Tão sempre a mesma, a Hora!... Balançar [de cimos de palma!..

Címbalos de Imperfeição... Ó, tão

[Antigüidade

A Hora expulsa de si-Tempo! Onda de

[recuo que invade

O meu abandonar-me a mim próprio até

[desfalecer,

E recordar tanto o Eu presente que me sinto [esquecer!...

Fluído de auréola, transparente de Foi, ôco [de ter-se...

O Mistério sabe-me a eu ser outro... Luar [sobre o não-conter-se...".

Apesar de Casais Monteiro ter afirmado que o próprio Fernando Pessoa renegara esses poemas como um compromisso do "futurismo" com o público do Portugal de então, talvez por isso mesmo eles nos dêem a impressão de uma confidência do que é a gente de língua portuguesa. Gente espalhada pelos cinco continentes, tão separada e 
no entanto tão unida por essa delirante ânsia de futuro radicada no passado. Esse constante estar só e em outras partes, esperando e se aventurando em coisas impossíveis do futuro. Esse atirar-se para as visões futuras do espaço sem fim, sonhando e esperando, porém sempre saudosa do passado originário.

Já se disse que a preocupação máxima de Fernando Pessoa ortônimo era a lucidez. Gilberto Kujawski observou-porém, com exatidão: “Todo afã de lucidez de Fernando Pessoa se reduz à consciência obsessiva de seus estados de consciência”. Em outro ensaio, Kujawski diz: "A psicologia da própria criação artística e da contemplação do mundo era objeto de sua lúcida consciência". Mas do que era autoconsciente o poeta? Ele se sabia, primeiramente, poeta, intermediário entre os deuses e seu povo. Isto se evidencia no poema XIII dos Passos da Cruz:

"Emissário de um rei desconhecido,

Eu cumpro informes instruções do além, E as bruscas frases que aos meus lábios vêm Soam-me a um outro e anômalo sentido...

Inconscientemente me divido

Entre mim e a missão que o meu ser tem, E a glória do meu Rei dá-me o desdém Por este humano povo entre quem lido...".

Mas não advertia talvez que sua missão, como poeta, era a de dizer o que ainda não fora dito: aquilo que se situa no limiar do inaudito. Mas efetivamente disse o que jamais fora dito; por exemplo:

"Ó tocadora de harpa, se eu beijasse Teu gesto, sem beijar tuas mãos, E, beijando-o, descesse p'los desvãos Do sonho, até que enfim eu o encontrasse

Tornado Puro Gesto, gesto-face

Da medalha sinistra - reis cristãos

Ajoelhando, inimigos e irmãos

Quando processional o andor passasse!".

Não creio que se tenha conseguido maior beleza em versos portugueses. Mas o que é esse gesto musical inatingível, tão real e tão ligado ao sonho? Será o indizível essencial que há por detrás de toda a gloriosa e exuberante festa do existir? O inefável gesto por detrás da existência nua da mão que tange a harpa. Creio que o poeta conseguiu revelar a beleza cristalina daquilo que é único, eterno e perfeito por detrás das aparências fugazes.

\section{RICARDO REIS}

De acordo ainda com a célebre carta sobre a origem dos heterônimos, enviada por Pessoa a Casais Monteiro, Ricardo Reis apareceu (sem que o poeta o percebesse), por volta de 1912, quando lhe veio à mente escrever poemas de índole pagã, em versos irregulares. A idéia não vingou, os poemas não saíram; mas foi entrevisto "um vago retrato da pessoa que estava a fazer aqui1o". Somente um ano e meio a dois anos depois, com a intenção de burlar-se de Sá Carneiro - seu amigo suicida - "inventou" um poeta bucólico: Alberto Caeiro, que aparece pronto e acabado na noite de 8 de março de 1914. "Aparecido Alberto Caeiro, tratei logo de lhe descobrir instintiva e subconscientemente uns discípulos. Arranquei do seu falso paganismo o Ricardo Reis latente, escolhi-me o nome e ajustei-o a si mesmo, porque nessa altura já o via". Surgiu então, entre outros, o poema:

"As rosas amo dos jardins de Adônis, Essas volucres amo, Lídia, rosas,

Que em o dia em que nascem,

Em esse dia morrem.

A luz para elas é eterna, porque

Nascem nascido já o sol e acabam”.

Lendo os versos acima, compreenderse-á o que desse heterônimo diz Pessoa: "Pus em Ricardo Reis toda a minha disciplina mental, vestida da maneira que lhe é própria”. Ricardo Reis, nascido em 1887 no Porto, formou-se em medicina e imi- 
grou para o Brasil em 1919, por ser monarquista, e onde vivia ainda em 1935. Era baixo e forte "de um vago moreno mate", homem cuja deliberada abstração só se concretizava em odes que em certos momentos lhe vinham de repente. Sem dúvida um epicurista, transformava as circunstâncias em algo semelhante ao que ele imaginava ser o mundo clássico em decadência uma vez que o epicurismo assim era entendido em sua época. O que transparece nos seus versos é que há um mundo da natureza anterior a nós, no qual estamos imersos. E a felicidade coincide com uma entrega total de si mesmo à sabedoria, sem pretender à glória ou a qualquer compensação dela decorrente. É o que exprime nestes versos:

“Antes de nós nos mesmos arvoredos Passou o vento, quando havia vento,

$\mathrm{E}$ as folhas não falavam

De outro modo do que hoje.

Passamos e agitamo-nos debalde

Não fazemos mais ruído no que existe Do que as folhas das árvores

Ou os passos do vento.

Tentemos pois com abandono assíduo

Entregar nosso esforço à Natureza

E não querer mais vida

Que a das árvores verdes".

Para o poeta, assim como para os gregos da decadência, além da natureza há um outro mundo - o da "alta praia onde o mar é tempo”. Mas tal mundo não nos pertence, mas aos deuses que tão distantes estão de nós, nesta época de carência. Apegamo-nos à certeza e à evidência imediata da natureza. Mas apesar disso:

"Acima da Verdade estão os deuses,

A nossa ciência é uma falhada, cópia

Da certeza com que eles

Sabem que há o Universo".

Pois bem, para ler as Odes de Ricardo Reis é necessário envolver-nos na ataraxia epicurista - aquela nobre e bela atitude de distância em que "todo desejo inquieto" se dissolve no amor da verdadeira "sabedoria"... por onde se pode alcançar a verdadeira "liberdade". E acima disso há a divindade: incorruptível, livre de preocupações e cuidados, acima de qualquer ira, assim como também de qualquer benevolência. Tanto o ódio como o amor são fraquezas humanas, incompatíveis com a perfeição dos deuses. Esperar serenamente a morte, quando nos tornamos "vultos solenes de repente antigos". A morte é a verdadeira libertadora de todo o terreno e doloroso apego às coisas e às pessoas. E quando chegar o momento: "Não tenhas nada nas mãos/ Nem uma memória na alma,/ Que quando te puserem/ Nas mãos o óbolo último,/ Ao abrirem-te as mãos/ nada te cairá./ Que trono te querem dar/ Que Atropos te não tire?/ Que louros que não forem/ Nos arbítrios de Minos?/ Que horas que te tornem/ Da estatura da sombra/ Que serás quando fores/ Na noite e ao fim da estrada?/ Colhe as flores, mas larga-as,/ Das mãos mal as olhaste./ Senta-te ao sol. Abdica/ E sê rei de ti próprio". Compare-se isto com o fragmento de Epicuro: "Habitua-te a pensar que a morte nada é para nós, visto que todo mal e todo bem se encontram na sensibilidade: e a morte é a privação da sensibilidade".

É sob a impressão profunda da ataraxia helenística que se deve ler a ode seguinte:

"Vem sentar-te comigo, Lídia, à beira do

[rio.

Sossegadamente fitemos o seu curso e

[aprendamos

Que a vida passa, e não estamos de mãos [enlaçadas.

(Enlacemos as mãos.)

Desenlacemos as mãos, porque não vale a [pena cansarmo-nos,

Quer gozemos, quer não gozemos,

[passamos como o rio.

Mais vale saber passar silenciosamente

E sem desassossegos grandes.

E se antes do que eu levares o óbolo ao

[barqueiro sombrio, 
Eu nada terei que sofrer ao lembrar-me

[de ti.

Ser-me-ás suave à memória, lembrando-te

[assim - à beira-rio.

Pagã triste e com flores no regaço”.

E desse pedaço de mármore frio roubado às minas de uma cidade antiga pelo "brasileiro" Ricardo Reis, passemos à labareda do último dos heterônimos de Pessoa.

\section{V. ÁLVARO DE CAMPOS}

Em abril de 1915 apareceu o primeiro número da revista Orfeu, e em maio, o segundo e último. No primeiro número publicou-se a "Ode Triunfal” e, no segundo, a “Ode Marítima”, ambas do poeta “futurista" Álvaro de Campos, um outro Fernando Pessoa. Em 1917, o único número da revista de Almada Negreiros, Portugal Futurista, publica o "Ultimato" de Álvaro de Campos, que se classificara a si mesmo como poeta sensacionista. Tanto os poemas como o "manifesto" correspondem à onda de insurreição insuflada por Marinetti que, nessa época, abalou a crítica de arte.

Álvaro de Campos apareceu como uma reação a Ricardo Reis, pois logo que Fernando Pessoa conseguiu “ver" Ricardo Reis, bateu a máquina, num jato, a "Ode Triunfal”. Assim surgiu, diz Fernando Pessoa, "a Ode com esse nome, e o homem com o nome que tem". Na mesma carta a Casais Monteiro, Pessoa revela que "Álvaro de Campos nasceu em Trevira, no dia 15 de outubro de 1890, à uma e meia da tarde (feito o horóscopo a essa hora, está certo)... é engenheiro naval (por Glasgow), mas agora está aqui em Lisboa, em inatividade... é alto $(1,75 \mathrm{~m}$ de altura, mais $2 \mathrm{~cm}$ do que eu), magro e um pouco tendente a curvar-se... Cara raspada... entre branco e moreno, tipo vagamente de judeu português, cabelo, porém, liso e normalmente apartado ao lado, monóculo".

Fernando Pessoa, ao explicar a gênese dos heterônimos, declara-se histérico ou hístero-neurastênico e afirma: "Se eu fos- se mulher - na mulher os fenômenos histéricos rompem em ataque e coisas parecidas -, cada poema de Álvaro de Campos (o mais histericamente histérico em mim) seria um alarme para a vizinhança”. Portanto, Álvaro de Campos seria para Fernando Pessoa rumor e estardalhaço, em reação à calma ataraxia de Ricardo Reis. Conseqüentemente, assim deve ser lido e entendido. Poder-se-ia dizer que os poemas de Álvaro de Campos são os que mais correspondem à imagem que se tem da vida real de Pessoa. Vivendo em Lisboa de 1914 a 1936, da primeira Guerra Mundial até o expurgo stalinista, sua situação não difere essencialmente da de Yeats, de Eliot, de Pound, que vivem em Londres ou Paris. São poetas de um tempo de carência (na expressão de Hölderlin), enquanto uma arte menor que a deles explode e se fragmenta nos diversos movimentos modernistas e futuristas. São eles os poetas “ D'entre deux guerres", cujo valor só será estabelecido em termos adequados em 1945 e depois. São filhos tardios do simbolismo e embora também contaminados pela iconoclastia revolucionária do futurismo, conservam a preocupação do arcaísmo, implícito em tudo que é simbólico. Nãoé Alberto Caeiro, nem Ricardo Reis, ou Fernando Pessoa que mais agudamente participam dessa situação. Álvaro de Campos é quem a vive intensamente. É ele, em Fernando Pessoa, o poeta europeu, irmão dos grandes de seu tempo, com eles participando do que deveria ser vivido e transmitido ao seu povo. Pode-se dizer, de certo modo, que Álvaro de Campos é mais Fernando Pessoa do que o próprio Fernando Pessoa. É ele quem fala no "antiquíssimo de nós", no fragmento da ode que começa:

"Vem, Noite, antiquíssima e idêntica, Noite Rainha nascida destronada, Noite igual por dentro ao silêncio, Noite Com as estrelas lantejoulas rápidas No teu vestido franjado de Infinito.

Vem, vagamente,

Vem, levemente, 
Vem sozinha, solene,

\section{Nossa Senhora}

Das coisas impossíveis que procuramos

[em vão,

Dos sonhos que vem ter conosco ao [crepúsculo, à janela

Vem, e embala-nos,

Vem e afaga-nos

Beija-nos silenciosamente na fronte

Tão levemente na fronte que não saibamos [que nos beijam

Senão por uma diferença na alma.

E um vago soluço partindo melodiosamente Do antiquíssimo de nós

Onde têm raiz todas essas árvores de

[maravilha

Cujos frutos são os sonhos que afagamos e [amamos

Porque os sabemos fora de relação com o [que há na vida”.

Pensemos nos "instructors" de Yeats, na figura do "jardim das rosas" de Eliot no "Anjo terrível", de Rilke, nas "personae" de Pound, e compreenderemos a unidade da grande poesia européia da primeira metade do século XX.

Na origem de nossa cultura, o protótipo desta poesia se encontra no hino à Noite, de Orfeu:

"Eu vou cantar aquela que gerou homens e [deuses, eu vou cantar a Noite.

A Noite é a fonte do universo, Cipris é

[também seu nome.

Ouve-nos, divindade bem-aventurada, [cintilante de estrelas,

Negro Sol, que alegra e torna calmo o sono [múltiplo.

Ó felicidade, ó deslumbramento, Rainha

[das vigílias, Mãe dos sonhos,

Ó Consoladora, que acalmas todas as

[misérias.

Ó adormentadora, Cavaleira, Luz negra,

[Amiga universal,

Ó Inacabada, que ora pertences ao céu, ora [à terra:

Ó arredondada, que brincas com

[tenebrosos ímpetos,
Ó tu que expulsas a luz do reino dos mortos [e a ele retornas.

A terrível Fatalidade é de todas as coisas a [soberana!

Ó Noite bem-aventurada, fartura de [delícias, ó universal ternura, Escutando a voz que, súplice, te implora, [possas, ó Indulgente, Livrar-nos dos terrores que brilham na [sombra

E ser-nos propícia” (*).

Esta matriz órfica revela-se claramente na ode fragmentária de Álvaro de Campos. Mãe e fonte de todo o imaginário, o "antiquíssimo de nós" é uma antevisão poética do inconsciente coletivo.

O transbordamento desses sonhos do profundíssimo toma, muitas vezes, a forma de um ilimitado amor pela natureza, ou pelo mundo moderno, tal como é, com toda a sua problemática, ou então se manifesta num exaltado sentimento de fraternidade humana. Tudo isso, num tom em que se percebe o acento lamentoso e ambivalente de um amor infeliz. Podemos percebê-lo na "Ode Triunfal” e na “Ode Marítima” e, também na saudação a Walt Whitman. "Amo-vos a todos, a tudo, como uma fera/ Amo-vos carnivoramente,/ Pervertidamente e enroscando a minha vista/ Em vós, ó coisas grandes, banais, úteis, inúteis/ Ó coisas todas modernas". E não é raro que esse frenético amor pela humanidade seja transfigurado no simbolismo da viagem - e na mais simbólica das viagens: a marítima -,percorrendo os mares que abraçam, mas que também separam toda a humanidade. Como deve ressoar fortemente para um português "o chamamento confuso das águas".

“E eu, que amo a civilização moderna, eu [que beijo com a alma as máquinas Eu o engenheiro, eu o civilizado, eu o

[educado no estrangeiro,

Gostaria de ter outra vez ao pé da minha

[vista só veleiros e barcos de madeira,

De não saber doutra vida marítima que a [antiga vida dos mares!

Porque os mares antigos são a Distância
Tradução de Dora Ferreira da Silva 
[Absoluta, O Puro Longe, liberto do peso do Atual... $\mathrm{E}$ ah, como aqui tudo me lembra essa vida [melhor,

Esses mares, maiores, porque se navega [mais devagar. Esses mares misteriosos, porque se sabia [menos deles".

A princípio, a “Ode Marítima” é a evocação da viagem como aventura pelos mares do mundo, a encontrar estranha gente em lugares estranhos. Mas logo se transforma no mergulho pelos mares tenebrosos da obscura interioridade, onde há piratas terríveis, sedentos de sangue, cheios de crueldade e paroxismo. Mas tudo termina, num tom ao mesmo tempo sarcástico e seco, pela retomada da regularidade exigida pelo tráfego comercial, dirigido por faturas e cartas protocolares, que garantem a segurança da carga a ser conduzida a destino certo.

$\mathrm{Na}$ "Saudação a Walt Whitman", logo percebemos a identificação do poeta Álvaro Campos com o poeta americano. Se antes, na “Ode Marítima”, se entregara femininamente a todas as violações, de tudo participando na própria carne, na "Saudação" é uma pessoa objetiva como totalidade de irrestrito amor por tudo o que há: mares do mundo e subjetividade profunda, corpo e alma, dentro e fora. "E conforme tu sentiste tudo, sinto tudo, e cá estamos de mãos dadas,/ De mãos dadas, Walt, de mãos dadas, dançando o universo na alma”.

“Ó sempre moderno e eterno, cantor dos [concretos absolutos, Concubina fogosa do universo disperso, Grande pederasta roçando-te contra a [diversidade das coisas,

Cantor da fraternidade feroz e terna com [tudo".

É impossível não ver nessa imagem do amante incondicional da totalidade, que quer ser ativamente masculino e, ao mesmo tempo, mulher violentada em sua ânsia amorosa por tudo, o poeta português, muito mais do que Walt Whitman. Nessa sau- dação, que é muito mais o retrato do primeiro do que do segundo, compreendemos o modo de ser de Pessoa, e muito pouco do poeta de Leaves of Grass. Caeiro - a sensação e o corpo de todos os heterônimos e do próprio Pessoa - parece intervir em certas passagens:

"Não quero intervalos no mundo!

Quero a contigüidade penetrada e material [dos objetos!

Quero que os corpos físicos sejam uns dos [outros como as almas, Não só dinamicamente, mas estaticamente [também!".

É o mesmo transbordamento insaciável que dá prosseguimento à "Passagem das Horas", poema de 1916: "Trago dentro do meu coração/ Como num cofre que se não pode fechar de cheio,/ Todos os lugares onde estive,/ Todos os portos a que cheguei,/ Todas as paisagens que vi através de janelas ou vigias, / Ou de tombadilhos, sonhando,/ E tudo isso, que é tanto, é pouco para o que eu quero".

Mas aqui já começa a desilusão de tudo querer imaginativamente. Desilusão filha da inadequação entre o que é imaginado e o que há.

“Dói-me a imaginação entre o que é [imaginado e o que há. Declina dentro de mim o sol no alto mar.

Eu sinto que ficou fora do que imaginei [tudo o que quero, Que embora eu quisesse tudo, tudo me

[faltou".

Esse estado de espírito parece sofrer uma interrupção melancólica em “A Casa Branca Nau Preta”, escrito em 1916. Álvaro de Campos, o sensacionista, desaparece, para reaparecer como o suicida potencial, no recado enviado a Daisy, sob a forma do "Soneto já Antigo", datado de 1922. Em 1923, Lisboa foi revisitada por Álvaro de Campos: "Não, não quero nada/ já disse que não quero nada./ Não me venham com conclusões!/ A minha única conclusão é 
morrer./ . . . / ó mágoa revisitada, Lisboa de outrora e de hoje!/ Nada me dais, nada me tirais, nada sois que eu me sinta./ Deixem-me em paz!/ Não tardo, que eu nunca tardo. . ./ Enquanto tarda o abismo e o silêncio, quero estar sozinho!". Foi porém em abril de 1926, após a segunda "Lisbon Revisited", que o poeta confessa: "Nada me prende a nada./ Quero cinqüenta coisas ao mesmo tempo./ Anseio como uma angústia de fome de carne/ $\mathrm{O}$ que não sei que seja".

E então o suicida aparece em Álvaro de Campos. Ou teria aparecido em Fernando Pessoa e só testemunhado por Álvaro de Campos?

"Se te queres matar, por que não te queres [matar?

Ah, aproveita! que eu tanto amo a morte e [a vida,

Se ousasse matar-me, também me mataria

Encara-te a frio, e encara a frio o que

[somos...

Se queres matar-te, mata-te...

Não tenhas escrúpulos morais, receios da

[inteligência!

Que escrúpulos ou receios tem a mecânica

[da vida?".

Mas tudo, em Álvaro de Campos, deve ser adiado. Até a morte desejada e o suicídio.

“Depois de amanhã, sim, só depois de

[amanhã.

Levarei amanhã a pensar em depois de

[amanhã

E assim será possível; mas hoje não...”.

A poesia de Álvaro de Campos provém do mais espontâneo e profundo e, portanto, do mais verdadeiro de Fernando Pessoa. Ela brota do "antiquíssimo de nós", é propiciada pela Noite, no sentido órfico da palavra, fonte obscura de toda realidade, Grande Mãe, sede da paixão criadora. É a poesia da totalidade do que existe: da extrema doçura à mais cruel violência. Vai desde a percepção direta (como lhe ensinou a perceber seu mestre Caeiro), até a mais intrincada conjetura, desde o absurdo irracional, até a mais alta especulação, que só a razão pode acolher.

Creio, porém, que não só a essência da poesia de Álvaro de Campos, mas também a própria essência do que é ser poeta poderá ser encontrada em dois de seus poemas. A primeira, assim começa: "Ao volante do Chevrolet pela estrada de Sintra". O poeta é aquele que, sempre em viagem pelos grandes caminhos do mundo, ou pelas infindáveis veredas da imaginação, sempre espera pela nova partida, e há, sempre, que arrumar as malas. Às vezes, entretanto, pode ocorrer também que "Hoje é a véspera de não partir nunca". O poeta segue, contudo, "sem haver Lisboa deixado ou Sintra a que ir ter". Sempre estará “na estrada de Sintra, ou na estrada do sonho, ou na estrada da vida..." e inclusive diante da grande viagem que o levará ao que não pode encarar de frente.

"Guiando o Chevrolet emprestado,

[desconsoladamente

Perco-me na estrada futura, sumo-me na

[distância que alcanço

E, num desejo terrível, súbito, violento,

Acelero...

Mas o meu coração ficou no monte de [pedras, de que me desviei ao vê-lo sem vê-lo". [inconcebível,
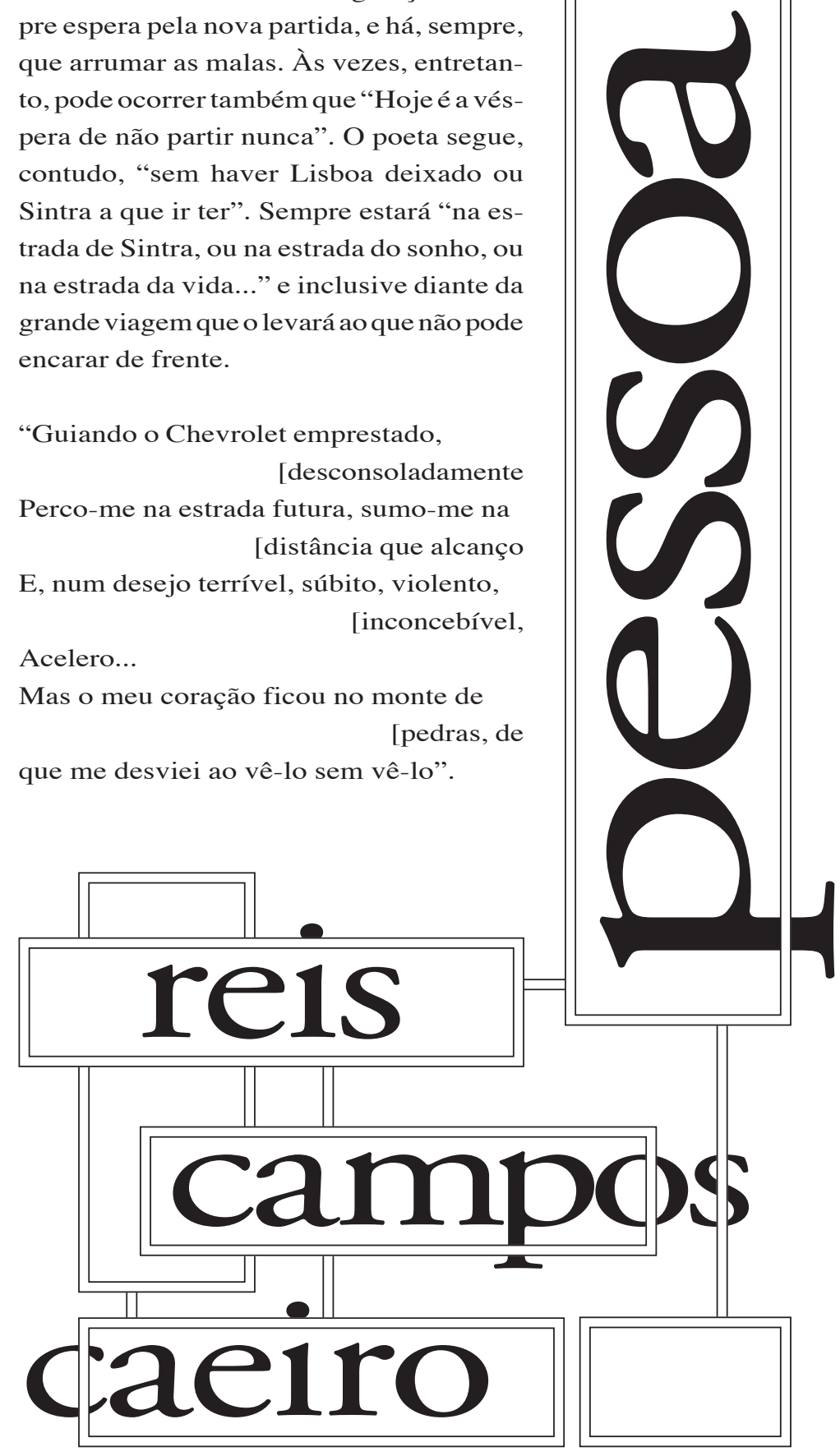
Todas as viagens levam, porém, a parte alguma senão ao centro de si mesmo, àquele em que se está sozinho, "enquanto tarda o Abismo e o Silêncio".

$\mathrm{Na}$ "Tabacaria", o poeta se define pela negativa: "Não sou nada./ Nunca serei nada./ Não posso querer ser nada./ À parte isso, tenho em mim todos os sonhos do mundo". Observador inserido na vida e no mundo, o poeta observa e dá sentido a tudo, como se estivesse fora dele. E nessa posição se divide entre a exterioridade do que vê e sente, e a interioridade do que pensa e imagina, a ambas tendo como reais e irreais.

“A tabacaria do outro lado da rua, como [coisa real por fora

E a sensação de que tudo é sonho, como coisa real por dentro."

Eterno fracassadoé o poeta, diante de si e do mundo, sonhando ganhar batalhas ganhas pelos generais, sonhando construir obras que os arquitetos constroem, sonhando fazer a filosofia que os filósofos escrevem. Ele é sempre "o que não nasceu para isso", "o que só tinha qualidades", o que "cantou a cantiga do Infinito numa capoeira/ E ouviu a voz de Deus num poço tapado". "Escravos cardíacos das estrelas", os poetas conquistam o universo antes de se levantarem da cama. Permanece, no entanto "a caligrafia rápida destes versos,/ Pórtico partido para o Impossível”.

Entre as inspiradoras formas femininas e o mundo real que vê, por fora, como estrangeiro em viagem, longe da pátria, é o poeta, no entanto, que confere realidade a tudo o que vê: "Porque é possível fazer a realidade de tudo isso, sem fazer nada disso”. Há os poemas que o poeta faz, e há a tabuleta da tabacaria. Tudo passará, com o tempo, e no entanto, "sempre haverá gente fazendo coisas como versos e vivendo por baixo de coisas como tabuletas". Mas o mundo sempre e continuamente restitui o poeta ao imediato, como nos últimos versos da "Tabacaria":
"Com um instinto divino o Esteves

[voltou-se e viu-me.

Acenou-me adeus, gritei-lhe Adeus ó

[Esteves! e o universo

Reconstruiu-se-me sem ideal sem

[esperança, e o Dono da Tabacaria sorriu".

\section{AFINAL FERNANDO PESSOA, ELE MESMO}

Mas afinal, dentre essa profusão de personagens, quem era o autor? Quem era Fernando Pessoa, ele mesmo? De quem, a consciência lúcida, capaz de manter harmoniosamente a sensibilidade física de Caeiro, a pura inteligência de Ricardo Reis e o sensacionismo total de Álvaro de Campos? De quem eram esse corpo, essa alma e esse espírito dessa pessoa de gênio, mal reconhecida, vivendo uma vida marginal num país periférico? O pobre e infeliz escrevente, tradutor comercial, adepto do ocultismo, fazedor de horóscopos, que viveu em Lisboa, entre 1914 e 1936 ?

Fernando Pessoa nasceu em 1888, no Largo de São Carlos, “a sua aldeia”. Passou a infância na África doSul, onde seu padrasto era cônsul português. Teve uma educação inglesa. Por isso, estreou como poeta de língua inglesa, em 1908. Em 1918 publica a plaquete 35 Sonnets, que mereceu então um comentário indulgente num jornal inglês. Seu único livro publicado em vida foi Mensagem, em 1934, concorrendo a um concurso literário que perdeu. Em 1913 apareceram seus poemas Impressões do Crepúsculo e Hora Absurda. Mas só a partir do primeiro número da revista Orfeu (1914), aparece o Pessoa ortônimo. Os heterônimos continuaram a ser publicados na revista de Coimbra Presença, até fins de 1938, mais de dois anos após sua morte. Só em 1942 apareceram suas Obras Completas e a partir dessa data a presença múltipla desse homem que foi vários pôde ser desenhada como esse núcleo uno e intenso que se chama Fernando Pessoa. 